\title{
Social Mobility and Cultural Reproduction of Javanese Descendant Community in Bangkok, Thailand
}

\author{
Nugroho Trisnu Brata \\ Universitas Negeri Semarang \\ trisnu_ntb2015@mail.unnes.ac.id
}

\begin{abstract}
There is a settlement of Javanese ethnicity in Sathorn District, Bangkok City. Although they claimed themselves to Javanese descendants, they are not good at speaking Javanese language. The purposes of this article are; (1) to describe the existence of the Javanese descendants in Bangkok City, Thailand, and (2) to know how the reproduction of Javanese culture is performed. The method used was qualitative research method. Data collection techniques used were observation, interviews, and literature review. Field observation in Sathorn, Bangkok, Thailand was conducted in July 2016. The results of this study showed that their ancestors originated from Kendal and Demak in Central Java who performed social mobility to Bangkok to build Lumbini park by the end of the 19th century. The affirmation of their Javanese identity was not by preserving the use of their mother tongue, Javanese language. The affirmation of the identity was centralized on the existence of the Javanese mosque as their cultural behavior. The Siamese ultranationalism (1939-1947), which aimed at forming a Siamese State based on one religion, nation, language and culture, has hampered the preservation of Javanese language among the diasporic Javanese ethnicity in Bangkok. The use of Thai language in sermons in the Javanese mosque, called as kenduri or selamatan, and sungkeman is a form of cultural reproduction of Javanese descendants who are influenced by their new environment in Bangkok dominated by Thai culture and language.
\end{abstract}

Keywords: cultural reproduction, Javanese descendant community, Javanese mosque, social mobility

\section{INTRODUCTION}

Bangkok City is the capital of the Kingdom of Siam that is now renamed the Kingdom of Thailand and is located quite far away from the island of Java. The existence of the Javanese community in Bangkok City is quite interesting to study because there are only few people who master the Javanese language. However, they still recognize or are even proud to be descendants of Javanese ethnicity by still preserving the Javanese tradition at certain times. Javanese people are often reluctant to wander or do mobility to distant places because they are very attached to parents, family land, and ancestral graves. This is very different from the Minangkabau and Batak people who have wandering tradition in their culture.

The purposes of this article are; (1) to describe the existence of the Javanese descendants in Bangkok City, Thailand, and (2) to know how the reproduction of Javanese culture is performed.

In general, the social mobility of various social groups has become a very common phenomenon. This implies that the cultural environment of each person can vary depending on the mobility behavior of a person or group of people. It also means that every group of people is faced with new values that require them to adapt constantly. In these situations, anthropological studies are relevant to question how a person or group of people can maintain their original cultural values. This is given that the area of culture is no longer important in the process of giving meaning to individual life because the cultural area of a person changes when he/she moves from one place to another [1]. In this context, the existence of the Javanese descendants in Bangkok is also of interest to the question of how they reproduce their culture originating from Java.

\section{METHOD}

The method used was qualitative research method. Data collection techniques used were observation, interviews, and literature review. Field observation was conducted in July 2016. The object of this study was the Javanese people who live in Kampung Jawa (Javanese Village) in Sathorn District, Bangkok, Thailand and they are Muslims. The informants who were the sources of the data were the elders as the grandchildren (third generation) of the Javanese people who came and settled in Bangkok. From Surasak MRT (BTS SkyTrain) station, Kampung Jawa can be reached by car, taxi, tuk-tuk, ojek (motorcycle taxi) or by walking down the thanon (road) or soi (alley). Visitors must be careful when walking down the Soi (road) Charoen Rat 1, Yaek 9 in the narrow Javanese Village in order not to get hit by speeding vehicles.

\section{RESULTS AND DISCUSSION}

\section{The Social Mobility of Javanese Community}

There is a Java Mosque or Cawa Mosque (Thai dialect) in Kampung Jawa, with traditional joglo architecture. In the island of Java, a joglo house building 
becomes a marker that the owner is a noble or priyayi in the social structure of Javanese society. The most popular and oldest joglo-model mosque is Demak Great Mosque of Demak Sultanate which was established in 1482-1549 M [2] in Demak City, Central Java. There is a large and shady Muslim cemetery across the Mosque, without any tombstone appearance like in Java. There are also some Halal (Muslim) restaurants around the mosque. Nowadays, the people of Kampung Jawa are not only composed of Javanese but also the Chinese and Thai Muslim mixed people.

The third generation of Javanese descendants in Bangkok is still able to converse with Javanese ngoko (informal style) but unable to speak Javanese krama madya or krama inggil (polite style). However, the fourth and fifth generations are not even able to speak either Javanese or Indonesian language. The names of people like Supri or Makrifah also have Thai nuances, such as Supri into Suppor and Makrifah into Ramphai, while the word Jawa into Cawa.

The existence of Javanese ethnic group in Bangkok seemed to be unique. Compared to Minangkabau or Bugis ethnic groups in Indonesia, Javanese ethnic group has actually lower level in migration or horizontal social mobility. According to [3], Javanese community finds difficulty to migrate because of the influence of Javanese cultural values, namely; mangan ora mangan waton kumpul (togetherness is important in any condition even without food). The ideal condition for Javanese society is always in togetherness both in the pleasant (described by mangan/eating or having food) and unpleasant conditions (described by ora mangan/no eating or having no food). The meaning of togetherness is expressed in residence. The pattern of residence is usually around either parents, in-laws, or relatives. In this condition of togetherness, the soul of gotong royong (communal work) is alive. If there is a difficulty and disaster or even a celebration, the relatives will soon provide assistance. Migrating and settling in distant places will make it difficult to ask for help from relatives in the event of a disaster.

Furthermore, according to Sairin, on the other hand, the ethnocentrism values of Javanese culture about the concentric circle that is centered on the King surrounded by circles; kraton (palace), kutho negoro (capital city), negoro agung (country), mancanegara (foreign countries), and sabrang (overseas area) are also influential in the low migration of Javanese society. Regarding this concentric circle (Selo Soemardjan, 1991) [4], it is stated that the outermost circle of Sabrang (overseas area) is seen as an area outside Java with bad cultural domain because its inhabitants are rude people who have bad behavior and are uncivilized. Although the Javanese also perform migration, they are usually still in the Javanese cultural domain, but avoid migration to Sabrang (overseas) areas.

The migration of Javanese people to sabrang (overseas) areas such as to Deli in Sumatera Utara, Suriname, or Bangkok, were most likely in forced conditions. Those who migrated to Deli and to Suriname were not voluntarily. The rural Javanese male population who still has a strong manpower was persuaded by the plantation of laborers. Promised with wages as workers in plantation areas and beautiful wife, the villagers who initially refused were persuaded by the brokers and went to the port and got into the ship. Inside the ship, the villagers were locked up and could not get out of the ship while waiting for other villagers persuaded by the brokers. After the brokers getting enough people, they asked the ship to go to the overseas areas and the villagers were forced to work on the plantations of Dutch companies. In the new place, they built a colony of Javanese community and made descendants.

According to National Archieves of Thailand (NAT), as stated by Ghofar Ismail, staff of the Indonesian Embassy in Bangkok, that the Javanese community in Bangkok in the 19th century of King Rama V (King Chulalongkorn) had traveled to island of Java. One of the places he visited was Bogor Botanical Gardens. In the following days, the Kingdom of Thailand brought workers from Kendal and Demak, Central Java, to build Lumbini Park (Lumpini Park), which was similar one to the Bogor Botanical Gardens in the island of Java. They also brought the Javanese sour tree like the one in Bogor Botanical Gardens. Currently, Lumbini becomes the icon of City Park in Bangkok (Kompas, September 11, 2016). Another source said that the existence of Kampung Jawa in 2013 has a population of 3,000 people in the middle of Bangkok City seems to be unique. All the people of Kampung Jawa have embraced to Islam. The Kampung Jawa area was a gift from the Kingdom of Thailand. It was all from the visit of King Chulalongkorn to Java in 1896. Then, King Chulalongkorn asked for help from Kings in Java to send sculptors and workers to build the park. King Chulalongkorn would provide shelter for these workers (DetikNews, March 1, 2013).

By the end of the 19th century, the Javanese kingdoms (Surakarta and Yogyakarta) were under the Dutch colonialism. At that time, the King of Surakarta was Susuhunan Pakubuwono X (1893-1939 AD), while the King of Yogyakarta was Sultan Hamengkubuwono VII (1877-1921 AD). At that time, the Javanese Kingdom had no power over the north coast of Java because the regents were under the control of the Dutch colonial government [4]. Kendal and Demak districts where Javanese workers led by regents who were under the control of the Dutch government, had most likely sent the workers to Bangkok on the command of the regents, not of the Kings.

\section{The Reproduction of Javanese Culture}

In Kampung Jawa, there is a Javanese Mosque which was completely built in $1908 \mathrm{AD}$ on a parcel of land of $3,500 \mathrm{~m} 2$. The building covers about $370 \mathrm{~m} 2$ with traditional Javanese architecture which has four pillars/soko guru (main pillars) and pyramid-shaped roof. There is a madrasah or an Islamic school, terrace, and a large Muslim cemetery across the road [5]. The traditional Javanese style mosque has become a marker of the existence of Javanese Muslim community in that place. 
The Javanese traditions kenduri (community gathering) and selamatan (communal feast) are still carried out in Kampung Jawa. Kenduri is usually held in terrace of the Javanese Mosque. Similarly in Java, kenduri is attended by the Muslims. They sit kneeling around nasi ambeng (ambeng rice), then after conducting prayer there are various traditional Javanese dishes served. During the prayer, they use a combination of Thai and Arabic languages. As well as in the sermon on Friday prayer, they use a combination of Thai and Arabic languages. Traditional Javanese dishes such as sayur asam (sour soup), oseng-oseng, nagasari cake, nasi kuning ambeng (ambeng yellow rice), and bolu kukus (steamed cake) are also served and consumed. Sungkeman tradition to parents or older relatives on Idul Fitri (Eid Day) is also still conducted. Sungkeman is a mutually apologize ritual through hand shaking in which the younger people apologize to the elders. Then, the older people give forgiveness, prayer, and blessings to the younger people. The island of Java is still a land that they long for. Its language, traditions, food, and even songs, especially for Bengawan Solo Song by Gesang, still attract the children of Javanese descendants in Bangkok (Kompas, September 11, 2016).

Culture in the form of cultural behavior such as kenduri and sungkeman is still maintained by people of Javanese descendants in Bangkok. Similarly, culture in the form of (cultural artifact) in the form of mosques, tombs, Islamic school, food, and music stands out as an affirmation of Javanese identity of the people in Kampung Jawa. Meanwhile, the Javanese language is not so prominent as the identity especially by the young generation of Javanese descendants. This seems to be related to the political conditions in the Kingdom of Siam/Thailand.

During the reign of Prime Minister Pibul Songgram, there was a Rathaniyom program launched, a program based on the Siamese ultra-nationalism. The aim of this program was to establish a true Siamese State based on one religion (Buddhism), nation, language, and culture of Siam. The whole programs were stated into seven decrees. In this period, the name Siam was changed to Thailand. For the Patani Malay community, the 1939 Rathaniyom program was a major disaster because it did not allow them to use the Malay name, to wear Malay dresses, to speak and write in Malay language, even to study Islam. It was in 1944 when Jawatan Kadhi was abolished and issues related to marriage and inheritance were based on the Civil Law, not on sharia law [6].

In addition to have negative effect on the Patani ethnic group, the Rathaniyom program had also some effect on other minor ethnic groups in Siam which was changed into Thailand. The effect was also perceived by the Javanese descendants in Bangkok. They were afraid to use the Javanese language due to fear of disobeying the Thai ultra-nationalism at the time. They then got used to speaking and reading in Thai, until the time of this research conducted. There were only few older people who are still able to speak ngoko Javanese. However, as time goes by and the freedom of religion and language for the non-Thai religion and ethnicity is implemented, everyone is accustomed to speaking in Thai language.

This article also borrows the concept of cultural reproduction as offered by Abdullah. According to [1], the process of cultural reproduction is an active process that affirms its existence in social life that requires adaptation for groups with different cultural backgrounds. Furthermore, [1] said that cultural reproduction is a process of affirmation of cultural identity carried out by immigrants, which in this case affirm the existence of the culture of origin. Parsudi Suparlan, for example, has demonstrated the existence of various forms of cultural expression that have intensified by the Javanese in Suriname.

The Javanese Mosque and Kampung Jawa have been created as the identity by the Javanese descendants in Bangkok. In regards to identity, [7] said that identity is not a final, static, and succeed entity, but something that always grows. Called it something that is never perfect, as it is always in the process and built from within. The word identity itself is a keyword that can refer to any connotation; social, political, cultural, and so forth. Identity for certain situations can mean worries, fears, or selfishness. For Javanese descendants in Bangkok, their identity in the form of cultural objects, cultural behavior, cultural arts, and traditional foods also means longing on the island of Java as the origin of their ancestors.

\section{CONCLUSION}

Based on the study conducted, it can be concluded that the affirmation of Javanese descendants identity in Bangkok does not preserve the use of the mother tongue of Javanese language. The affirmation of the identity is centered on the existence of the Javanese Mosque and the historical story of the arrival of the Javanese community to Bangkok due to the request of King of Siamese to build Lumbini Park/Lumpini Park. Siamese ultranationalism (1939-1947) aimed at forming a Siamese State based on one religion, nation, language, and culture has hampered the preservation of Javanese language among the diasporic Javanese ethnicity in Bangkok.

Although the Javanese descendants in Bangkok affirmed their Javanese identity through the existence of Javanese mosque with traditional Javanese architecture, the sermon is performed in Thai with a combination of Arabic language. Although they carry out kenduri or selamatan, they use a combination of Thai and Arabic languages while conducting prayer, not Javanese and Arabic as it should be in the island of Java. Although they still carry out the sungkeman tradition on Eid Day, they do not use the Javanese but Thai language. The use of Thai in sermons in the Javanese mosque, in kenduri or selamatan, and in sungkeman is a form of cultural reproduction of Javanese descendants who are influenced by their new environment in Bangkok dominated by Thai culture and language. 


\section{REFERENCES}

[1] Abdullah, Irwan. Konstruksi dan Reproduksi Kebudayaan. Yogyakarta: Pustaka Pelajar. 2007.

[2] Abdullah, Rachmad. Kerajaan Islam Demak Api Revolusi Islam di Tanah Jawa. Sukoharjo: Al Wafi. 2015.

[3] Sairin, S. Riak-Riak Pembangunan. Yogyakarta: Pustaka Pelajar. 2010.

[4] Brata, Nugroho T. Prahara Reformasi Mei 1998 Jejak-Jejak Kesaksian. Semarang: Unnes Press. 2006.

[5] Yusdani. The Live of Javanese Moslems in Sathorn Bangkok Thailand. International Journal of Business, Economics and Law, 9 (5)April, 82-89. 2016.

[6] Saifullah. Sejarah \& Kebudayaan Islam di Asia Tenggara. Yogyakarta: Pustaka Pelajar. 2010.
[7] Abdillah, S., Ubed. Politik Identitas Etnis Pergulatan Tanda Tanpa Identitas. Magelang: Indonesiatera. 2002.

[8] Brata, Nugroho T. Kekerasan Kampanye di Kota Jogja Studi Etnofografi Peristiwa Kampanya PPP 1997. Skripsi Strata 1 tidak diterbitkan, Universitas Gadjah Mada, Yogyakarta. 1997.

[9] DetikNews. Keramahan Khas Indonesia ala Kampung Jawa di Tengah Kota Bangkok. Jumat, 01 Maret 2013.

[10] Kompas. Kenangan Jawa di Sudut Bangkok. Minggu 11 September 2016. 